\title{
PASSIVE KIMBERLITIC FLUID EMPLACEMENT INTO DILATING DYKE-FRACTURE SYSTEMS IN SOUTH AFRICA
}

\author{
Ian Basson and Giulio Viola \\ Department of Geological Sciences, University of Cape Town, Cape Town, South Africa
}

\section{INTRODUCTION}

Three textural-genetic facies of kimberlite are presently recognized, each attributable to a specific mode of magmatism. Hypabyssal facies dykes, precursor dykes and root zones typically underlie and pre-empt the diatreme facies, which is in turn overlain by crater facies kimberlite (Hawthorne, 1975; Field and Scott-Smith, 1998). Exploitation of diatremes, consisting of tuffisitic kimberlite and/or tuffisitic kimberlite breccia, has provided much of the data used to infer the mechanisms of kimberlite emplacement and the form of feeder zone:diatreme transition (e.g. Clement, 1982). However, the structural development of underlying/precursor kimberlite dykes has yet to be addressed to the same extent as the feeder zones of other magma systems (e.g. Maloe, 1998; Lister and Kerr, 1991; Watanabe et al., 1999). Mid-Cretaceous kimberlites in southern Africa are divided into two groups, which also show a temporal clustering: Group I kimberlites (95-80 Ma) are ilmenitebearing with distinct $\mathrm{Pb}, \mathrm{Sr}$ and $\mathrm{Nd}$ isotopic ratios (Smith, 1983). In contrast, Group II kimberlites (145-115 Ma) are highly-micaceous and ilmenite-poor (op. cit). Only Group II kimberlite dykes are currently exploited in South Africa (e.g. Bellsbank/Bobbejaan, Ardo, Roberts Victor, Star, Klipspringer and Helam; see Gurney and Kirkley, 1996). The dykes are typically thin (maximum of $1.3 \mathrm{~m}$ wide), limited in strike extent (maximum of approximately $4 \mathrm{~km}$ ) and extend down-dip

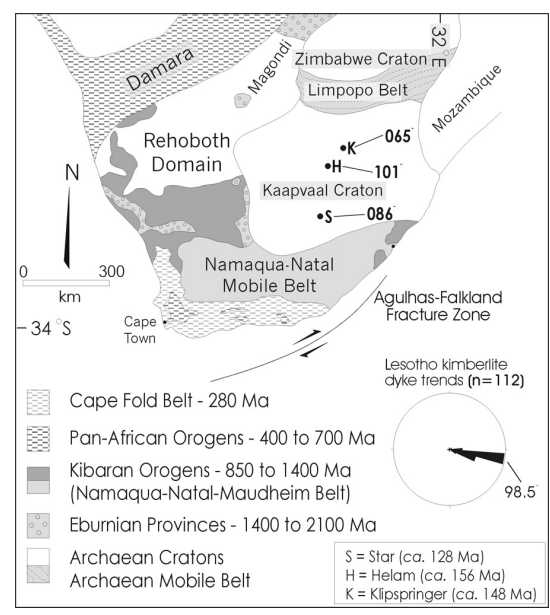

Figure 1: Position and array trends of the three Group II kimberlite dyke systems examined in this study (S:Star, H:Helam and K: Klipspringer). Also shown are the Agulhas-Falkland Fracture Zone and a rose diagram of Lesotho kimberlite dyke trends (average trend of $98.5^{\circ}$ ). for at least one kilometer with no systematic or discernable change in their grade, mineralogy and overall nature. Exploitation provides a unique opportunity to document their three-dimensional morphology and to infer their intrusion mechanisms. This study concentrates mainly on Star (Welkom gold fields area) and Helam (Limpopo Province) mines, although features from the Klipspringer Project (Limpopo Province) augment these observations (Figure 1). Dyke-fracture morphologies are briefly addressed, followed by a description of the investigated systems. Common structural features are described in detail and integrated with petrographic observations on key microstructures. A simple qualitative analysis of the dyke emplacement mechanism is given and the origin of E-W trending kimberlite dyke-fracture systems in the context of Gondwana break-up is suggested.

\section{DYKE-FRACTURE MORPHOLOGY}

Dyke-fracture systems combine a fracture system and a dilational vector field, with a magma or fluid occupying these fractures (Figure 2; Hoek, 1994). A dyke-fracture segment is a single, planar or curved, continuous element, potentially joining other segments in a jog (where two segments meet at a sharp angle); or branching, bifurcating or overlapping in an offset, where they are sub-parallel but not in-line along strike (e.g. irregular or braided arrays). While the term dyke is commonly applied to a dilated magmafilled fracture system consisting of several, minor subparallel segments, repetition of overlapping or nonoverlapping offsets comprise an en-echelon array with the array envelope or bounding margin defining the array trend. The local dilation vector relates to the relative offset of corresponding points on opposite wallrock contacts of a segment. Volumes of relatively intact rock between offset fracture segments are termed bridges, which may contain wedge-shaped kimberlite apophyses formed by rotation or fracturing of the bridge. Here the more generic term array is applied to a collection of dykes (q.v. Figure 2). Classification relies on: a) orientation of dyke segments w.r.t. the array envelope; b) observed or measured dilation direction; c) the presence and extent of jogs, bifurcations and offsets and d) the presence and abundance of parallel, fully overlapping dyke segments. As a first approximation, the dyke segments studied here are mainly left-stepping, overlapping dyke-fracture arrays with local right- or left-stepping offsets within individual dykes. 


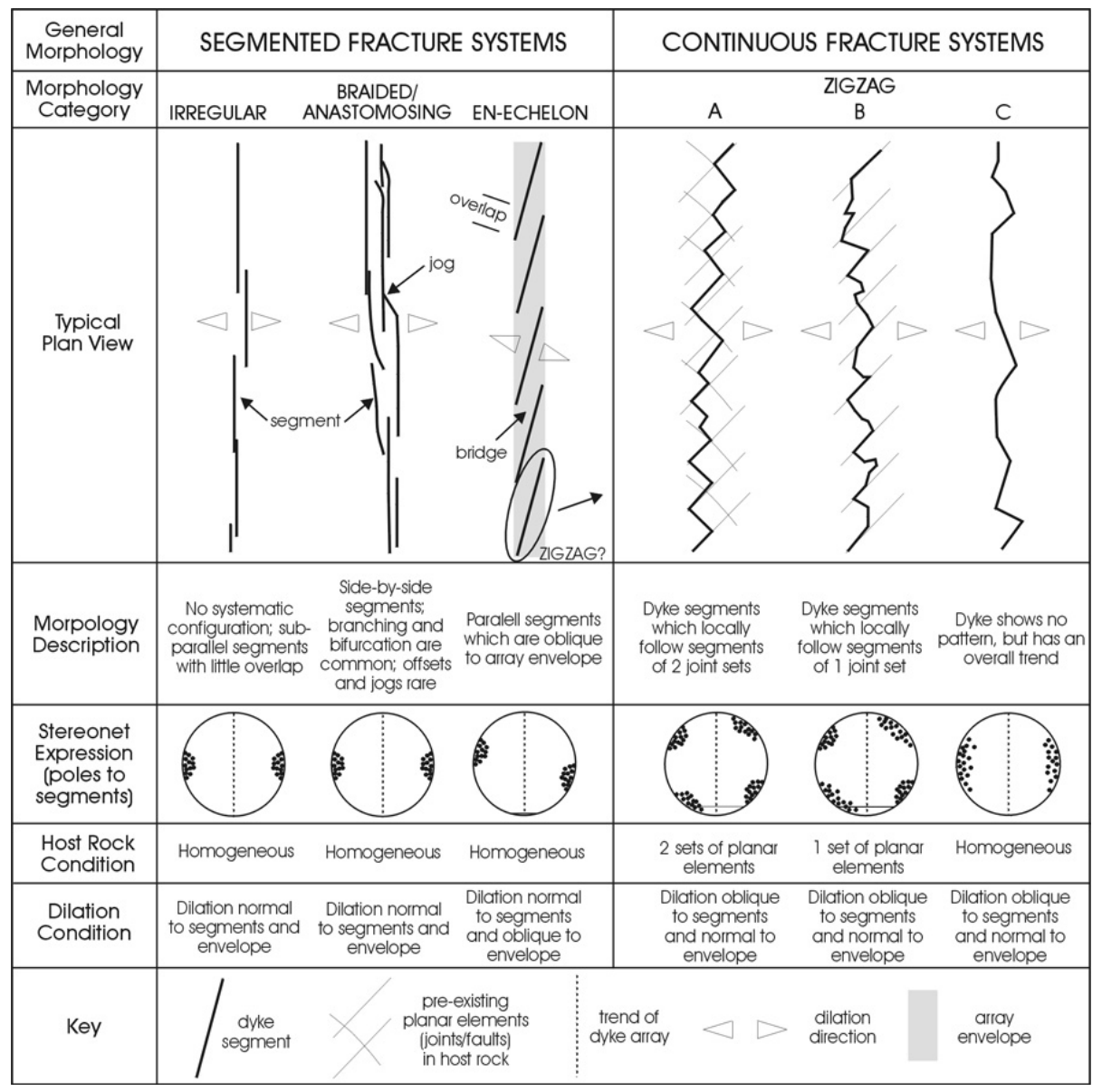

Figure 2: Summary of dyke-fracture systems (after Hoek, 1994).

Dykes locally show zigzag, or braided/anastomosing patterns. The angular difference between dyke array trends and array trends is typically less than $5^{\circ}$.

\section{MACRO-STRUCTURES}

\section{Dyke-Parallel fracture Cleavage}

An ongoing problem with kimberlite dyke mining is the "spalling" of country rock into newly excavated areas. Spalling exploits a ubiquitous dyke-parallel fracture cleavage surrounding the kimberlite dykes, extending in a zone up to $2 \mathrm{~m}$ wide on either side of the intrusive contacts (Figure 3a). The cleavage exhibits no signs of shearing, may contain fibrous calcite veining or may be locally infilled with thin kimberlite stringers. The fracture cleavage, termed "sympathetic" due to its parallelism with the intrusive contacts, is closer spaced (approx. 10-20 cm) in more fissile host rock such as dolerite and shale, but is more widely spaced (up to $50 \mathrm{~cm}$ ) in less fissile host rock (e.g. sandstone and bioturbated sandstone).

\section{Multiple Kimberlite Stringers and IN-Situ BRECCIA}

En-echelon kimberlite dyke arrays, unlike kimberlite diatremes and blows, are primarily breccia-free. Two common exceptions are known: 1) at the terminations of kimberlite dykes, where slivers of host rock with high aspect ratios, apparently utilizing the dyke-parallel sympathetic fracture cleavage, alternate with narrow kimberlite stringers; and 2) where fragments of host rock occur "in-situ", separated from the main host rock by thin kimberlite stringers (in-situ breccia or ISBs), but exhibiting very minor movement or transportation (Figure 3b).

\section{Fibrous Calcite VeINS}

Veins containing fibrous calcite crystals at right angles or very high angles to the vein margins are common within dykes, at dyke margins or occupying the sympathetic fracture cleavage in the host rock (Figure 3c). The orientation and form of calcite veins clearly demonstrates orthogonal fiber growth relative to the intrusive contact. Calcite fibers occur in a number of modes, usually not distinguishable underground or in hand specimen, which indicate similarly orthogonal calcite growth at various stages, from (nearly) syn-dyke emplacement to post-emplacement. 

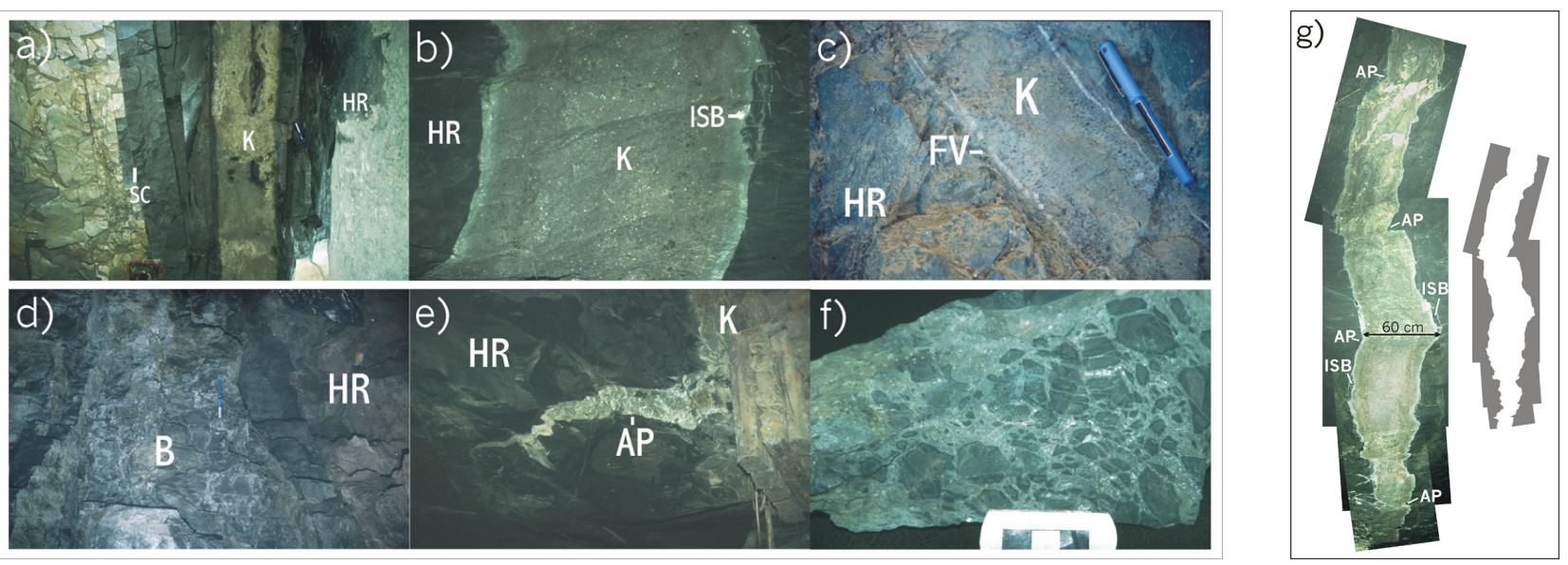

Figure 3: Macro-structures of kimberlite dykes a) Multiple parallel ("sympathetic") fracture cleavages (SC-East Star dyke, Star Mine, width of photo $=2 \mathrm{~m}$ ); b) "in-situ breccia" (ISB-Burns Dyke, Star Mine, width of dyke $=60 \mathrm{~cm}$ ); c) Fibrous calcite veinlets (FV-M8 Precursor dyke, Maarsfontein, width of dyke = $13 \mathrm{~cm}$ ); d) Breccia (B) in overlap areas between dyke segments (Helam Mine, width of zone $=70 \mathrm{~cm}$ ); e) Wedge-shaped apophysis (AP) where the host rock bridge between two overlapping segments has undergone non-elastic torsion (Burns Dyke, Star Mine, wooden pack at left is $1.2 \mathrm{~m}$ wide); $\mathrm{f}$ ) True kimberlite breccia in dyke "roll" (Wynandsfontein, Star Mine, scale in cm); g) Opposite dyke contacts, matching asperities and ISBs (Burns Dyke, Star Mine).

\section{Brecciated OVERLAP AREAS}

During mining, dyke termination and the exposure of multiple stringers pre-empts a major or minor lateral step. Such steps are accompanied by often-extreme brecciation of the host rock (Figure 3d). These areas are not intruded by kimberlite stringers, suggesting a kimberliteindependent mechanism for their formation. Highly brecciated ground between overlapping dykes is often pervasively altered, clay-rich and may be the site of underground cavities and high water yield. Brecciation comprises the whole width of a mining end, or may occur in kimberlitefree planar zones trending at acute angles to adjacent or overlapping dykes.

\section{Apophyses at BENT BRIDGES}

Kimberlite stringers or apophyses, at high angles to the main kimberlite dyke, occur near steps in en-echelon arrays (Figure 3e). The apophyses are wedge-shaped, with their widest parts merging with the adjacent dyke. These are caused by magma intruding into wedge-shaped cracks caused by non-elastic deformation (torsion or twisting followed by brittle failure) of the adjacent block of host rock, which essentially comprises a "bent bridge" between overlapping propagating/dilating en-echelon dyke-fracture segments (q.v. Figure 1 of Nicholson and Pollard, 1985; Figure 2).

\section{KIMBERLITE BRECCIA}

The development of kimberlite breccia (sensu stricto) occurs in blows, where a portion of the dyke widens, or where the dyke "rolls", that is, where an individual dyke locally assumes a near-horizontal disposition and is displaced laterally by up to $4 \mathrm{~m}$ (Figure $3 \mathrm{f}$ ).

\section{Matching Opposite Host Rock Contacts}

A limited number of localities underground reveal that dilation of the host rock was perfectly orthogonal to the strike of the kimberlite dyke segment (Figure 3g). Such exposures suggest that magmatic stoping and "violent" or explosive removal of host rock asperities was not the norm.

\section{MICROSCOPIC TEXTURES}

Ubiquitous thin (up to $5 \mathrm{~mm}$ wide) calcite veins commonly contain multiple fine, fibrous calcite crystals. Veins occur within host rock, at kimberlite:host rock contacts, and within the kimberlite (Figure 3c). Syntectonic vein growth occurs by the deposition of elongated fibrous quartz, calcite, chlorite, epidote and/or albite (e.g. Bons, 2000; Hilgers and Urai, 2002). Such fibres typically define the dilation direction of the host rock and link points that were once in contact with one another. Types of calcite veining are described according to a) their inferred age relative to the emplacement and crystallization of the kimberlite and b) the dilation direction of the host fracture (q.v. Figure 2). Four vein types (Types I-IV) are identified (Figures 4a-d; Stretched, Stretched to Syntaxial Elongate-Blocky, Antitaxial and Blocky). Type I to Type III veins show a natural progression of features. The incidence of brittle fracturing and extension of phlogopite macrocrysts and phenocrysts, the density of crack-seal inclusions and the progressive development of a median line increase from Type I to III. The aspect ratios of calcite fibres and the extent of resealing of phlogopite by newly crystallized phlogopite decrease from Type I-III. Highly elongate stretched fibre morphologies in Type I veins (Figure 4a) appear to have 
formed soon after intrusion. This is supported by the fact that veins do nor break or transect olivine or phlogopite macrocrysts; by the presence of internal, aligned vein phlogopite phenocrysts that exhibit syn-veining crystallization (sharp terminations at the contacts of adjacent calcite fibres); and by minimal brittle extension or associated crack-seal deformation. Patently, the contact of these veins, due to the thin, unstrained calcite fibres being rooted in matrix carbonate, was extremely competent and only occasionally allowed the utilization of one of its vein:host rock contacts for later veining episodes ("Composite" types). Type II-III veins (Figure 4b, c) were transitional, in terms of their features and timing relative to the emplacement of the related dyke, between Types I and IV. Type IV blocky veins (q.v. Figure 4d), with anastomosing formats, highly irregular margins, broken olivine/ phlogopite macrocrysts and late-stage quartz infill, evidently formed in a post-(main) intrusion/cooling stage.

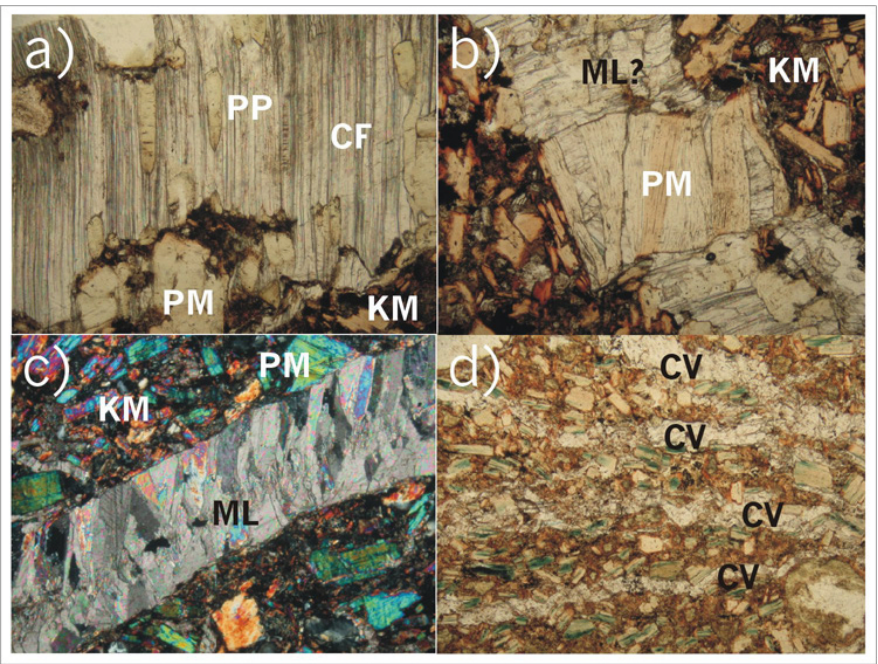

Figure 4: Vein Types I to IV; a) Type I - thin/high aspect ratio calcite fibres (CF) with aligned phenocrystic phlogopite (PP); b) $+c)$ Type II and III - calcite fibres are broader, cross-cut phlogopite macrocrysts (PM), grow antitaxially and veins may show a median line (ML) and d) blocky, irregular calcite veins $(\mathrm{CV}) . \mathrm{KM}=$ kimberlite matrix; Horizontal Field of View $=1.75$ $\mathrm{mm}$; a), b) and d) in PPL, c) in XPL.

\section{DISCUSSION}

An average ascent rate of $65 \mathrm{~km} / \mathrm{hr}$ is given for kimberlite magmas (Basson et al., 2002), similar to crack propagation rates through the brittle lithosphere at a few metres per second (Aki et al., 1977; Watanabe et al. 1999; Bons et al., 2001). Notwithstanding the volatile-rich nature of kimberlite and related magmas, a reasonable explanation of the extremely rapid ascent mechanism of these very lowvolume fluids is notably absent from the literature. Dilatant en-echelon fractures are found at a variety of scales, including fringe fractures on joints, quartz-filled veins, surface fractures in volcanic edifices, associated with shear zones and normal faults, and within strained and deformed metals and glasses (Pollard et al., 1982; Lawn, 1993). Macro- and micro-structural observations of kimberlite dykes suggest that initial and subsequent dilation of vein segments, at low twist angles to the array, was orthogonal to the trend of dyke contacts. Structural features in the host rock point towards a kimberlite-independent emplacement mechanism. The close relative time of emplacement of Type I fibres with respect to the actual intrusion/cooling event is augmented by the evidence for continued host rock dilation, independent of a magmatic overpressure, very soon after the dyke had started cooling, possibly shedding some light on the relative contributions of an independently dilating host rock and an overpressured magma. Mobile hydrofractures (e.g. Secor and Pollard, 1975; Giberti and Wilson, 1990; Bons, 2000) are a possible transport mechanism for kimberlitic magmas, wherein simultaneous dilation and closure of the upper and lower fracture tips may have occurred, respectively (Bons, 2000). The dilated part of the fracture and entrained fluid usually move rapidly upwards with little or no interaction with the host rock.

\section{CONCLUSION}

The development of fractures, their opening and filling (either by kimberlitic magma to form dykes or calcite to form veins) are part of failure by pure dilation orthogonal to dyke contacts. The Mohr-Coulomb theory of brittle failure predicts the formation of pure extensional, hybrid or shear fractures by plotting the differential stress conditions vs. the shear stress at the time of failure (Figure 5). Pure extensional fractures develop parallel to the greatest compressive stress $\left(\sigma_{1}\right)$ when the effective least compressive stress $\left(\sigma_{3}{ }^{\prime}\right)$ equals or exceeds the tensile strength $(\mathrm{T})$ of the rock. Such a condition is met only if the differential stress is less than 4T (a geometrical constraint imposed by the geometry of the Griffith failure envelope in the tensional field - Case 1, Figure 5). For large differential stresses the stress circle is tangential to the failure envelope and shear stress is non-zero along the failure plane (Cases 2 and 3, hybrid fracturing and shear, respectively), which is clearly not the case here as macro- and micro-structural features indicate no major shear component during or indeed after emplacement. The effect of increasing fluid or magma pressure within the system is shown in Cases 4 and 5 (Cox et al., 2001; Figure 5), for low differential stress and high differential stress, respectively. In Case 4, increasing the fluid pressure causes the stress circle, defining a small differential stress, to migrate to lower respective ('effective') normal stresses, thereby intersecting the failure envelope. In Case 5, increasing the fluid pressure at a high differential stress similarly causes the stress circle, defining a large differential stress, to migrate to lower effective normal stresses, thereby imparting shear to the system. Failure is induced by maintaining differential stress and increasing pore/fault fluid pressure or by maintaining a constant pore/ fault fluid pressure and increasing the differential stress. As the duration of earthquakes are of the same order of 
magnitude as the empirically-constrained emplacement period of kimberlites, a structural control is perhaps more likely in triggering kimberlitic magma ascent. A sudden change in the differential stress, defined by an initially small Mohr Circle is therefore proposed to be the trigger for fracture initiation and concomitant emplacement of kimberlite dykes in a fully coupled crust:mantle system. The largely N-S trending extension responsible for the remote stresses which formed these and other broadly E-W trending Group II dykes (q.v. the "Lesotho Trend"; Figure 1) throughout South Africa is probably the result of the early initiation of the dextral NE-trending AgulhasFalkland Fracture Zone (Ben-Avraham et al., 1997), which heralded the opening of the proto-Indian Ocean at $c a .170$ Ma (Figure 1). We propose that rapid kimberlite emplacement in dyke arrays concomitant with plate reorganization, is structurally triggered, is not achieved by magmatic stoping in the near surface environment and may furthermore be independent of sub-lithospheric hotspots or mantle plumes.

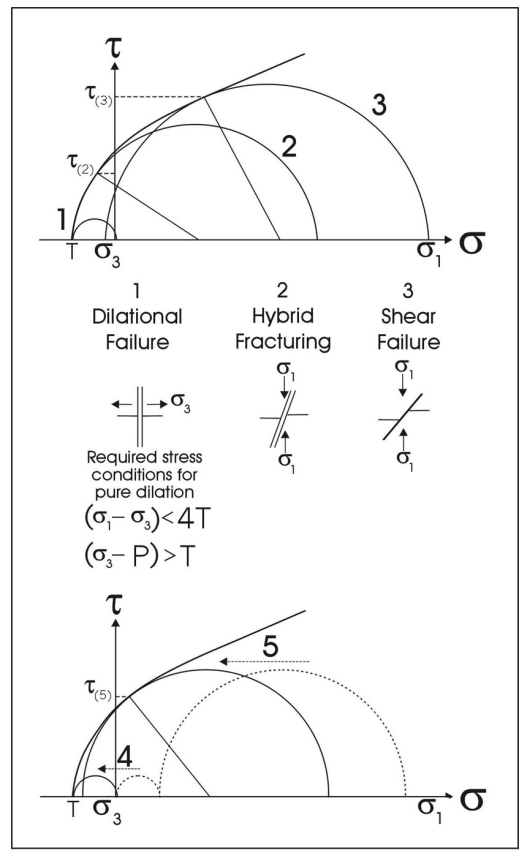

Figure 5: Possible stress conditions for kimberlite dyke-fracture formation - those dictated by Mohr Circles 1 or 4 are indicated from by this study. See text for details.

\section{REFERENCES}

Aki., K., Fehler, M. and Das, S., 1977. Source mechanisms of volcanic tremor: Fluid-driven crack models and their application to the 1963 Kilauea eruption. J. Volc. Geotherm. Res. 2, 259-287.

Basson, I.J., Jelsma, H. and Viola, G., 2002. Rapid kimberlitic fluid extraction from the lithospheric mantle. Ext. Abstr. IAGOD 11, Windhoek, Namibia.

Ben-Avraham, Z., Hartnady, C.J.H. and Kitchin, K.A., 1997. Structure and tectonics of the Agulhas-Falkland fracture zone. Tectonophysics $282,83-98$.

Bons, P.D., 2000. The formation of veins and their microstructures, In: Jessell, M.W. and Urai, J.L. (Eds.), Stress, Strain and Structure: A volume in honour of W.D. Means, J. Virt. Expl. 2.

Bons, P.D., Eldburg, M.A. and Dougherty-Page, J., 2001. Analogue modelling of segregation and ascent of magma. J. Virt. Expl. 4, 7-14.

Clement, R.C., 1982. A comparative geological study of some major kimberlite pipes in the Northern Cape and Orange Free State. Ph.D. Thesis, Univ. Cape Town, South Africa.

Cox, S.F., Knackstedt, M.A. and Braun, J., 2001. Chapter 1: Principles of Structural Control on Permeability and Fluid Flow in Hydrothermal Systems, In: Richards, J.P. and Tosdal, R.M. (Eds.), Structural Controls on Ore Genesis: Rev. Econ. Geol. 14, 1-24.

Field, M. and Scott-Smith, B.H., 1998. Contrasting geology and near-surface emplacement of kimberlite pipes in southern Africa and Canada. In: Gurney, J.J., Gurney, J.L., Pascoe, M.D. and Richardson, S.H. (Eds.), Proc. $7^{\text {th }}$ Int. Kim. Conf, Cape Town, South Africa, pp. 214-237.

Giberti, G. and Wilson, L., 1990. The influence of geometry on the ascent of magma in open fissures. Bull. Volc. 52, 515-521.

Gurney, J.J. and Kirkley, M.B., 1996. Kimberlite dyke mining in South Africa. Afr. Geosci. Rev. 3(2), 191-201.

Hawthorne, J.B., 1975. Model of a kimberlite pipe. Phys. Chem. Earth 9, 291-311.

Hilgers, C. and Urai, J.L., 2002. Microstructural observations on natural syntectonic fibrous veins: implications for the growth process. Tectonophysics 352, 257-274.

Hoek, H., 1994. Mafic Dykes of the Vestfold Hills, East Antarctica. Ph.D. Thesis, University of Utrecht, Netherlands.

Lawn, B.R., 1993. Fracture of Brittle Solids - Second Edition. Cambridge University Press, Cambridge, United Kingdom.

Lister, J.R. and Kerr, R.C., 1991. Fluid-mechanical models of crack propagation and their application to magma transport in dykes. J. Geophys. Res. 86, 10049-10077.

Maloe, S., 1998. Shape of ascending feeder dykes, and ascent modes of magma. J. Volc. Geotherm. Res. 81, 207-214.

Nicholson, R. and Pollard, D.D. (1985). Dilation and linkage of echelon cracks. J. Struc. Geol. 7, 583-590.

Pollard, D.D., Segall, P. and Delaney, P.T., 1982. Formation and interpretation of dilatant echelon cracks. Geol. Soc. Am. Bull. 93, 1291-1303.

Secor, D.T. and Pollard, D.D., 1975. On the stability of open hydraulic fractures in the earth's crust. Geophys. Res. Lett. 91(B), 842-860.

Smith, C.B., Allsopp, H.L., Kramers, J.D., Hutchinson, G. and Roderick, J.C., 1985. Emplacement ages of JurassicCretaceous South African kimberlites by the $\mathrm{Rb}-\mathrm{Sr}$ method on phlogopite and whole rock samples. Trans. Geol. Soc. S. Afr. 88, 249-266.

Watanabe, T., Koyaguchi, T. and Seno, T., 1999. Tectonic stress controls on ascent and emplacement of magmas. J. Volc. Geotherm. Res. 91, 65-78.

Contact: IJ Basson, Dept. Geological Sciences, University of Cape Town, Private Bag Rondebosch, 7701, South Africa

E-mail: ibasson@geology.uct.ac.za 